\title{
Treating male infertility
}

\author{
Paulo Franco Taitson, Antonio Mourthé Filho, Letícia Maria Fernandes Rodrigues
}

\begin{abstract}
Most causes of male infertility are treatable, and the goal of many treatments is to restore the ability to conceive naturally. The process of spermatogenesis is essential for human reproduction. A simple sounding process is mediated by a variety of factors, including multiple hormonal influences. Fertility should be discussed with all patients at risk of gonadal failure due to treatment. Ideally, this discussion should be held by a fertility expert with special interest in fertility preservation. This mini review aims to provide the current status of male infertility, the fertility preservation options and the impact of stem cells in it today.
\end{abstract}

Key words: male infertility, stem cells, andrology.

\section{RESUMO}

A maioria das causas de infertilidade masculina são tratáveis, e o objetivo de muitos tratamentos é restaurar a capacidade de conceber naturalmente. O processo da espermatogênese é essencial para reprodução humana, processo mediado por uma variedade de fatores, incluindo múltiplas influências hormonais. A fertilidade deve ser discutida com todos os pacientes em risco de insuficiência gonadal provável devida a um tratamento. O ideal é que essa discussão seja realizada por um especialista em reprodução, com especial interesse na preservação da fertilidade. Esta mini-revisão tem como objetivo proporcionar o status atual da infertilidade masculina, as opções de preservação da fertilidade e o impacto das células-tronco no tratamento hoje.

\section{INTRODUCTION}

Recent advances in reproduction treatment have enabled some couples with severe infertility issues to conceive, but the methods are not successful in all cases. Notwithstanding the significant financial burden of assisted reproduction treatment, the emotional scars from an inability to conceive a child enacts a greater toll on affected couples. While methods have circumvented some root causes for male and female infertility, often the underlying causes cannot be treated, thus true cures for restoring a patient's fertility are limited. Furthermore, the procedures are only available if the affected patients are able to produce gametes. Stem cells represent a future potential avenue for allowing sterile patients to produce offspring. Advances in stem cell biology indicate that stem cell replacement therapies may be on the horizon to treat and possibly cure male and female infertility, although significant challenges need to be met before this technology can reach clinical practice (Easley, 2013).

\section{MALE INFERTILITY: CURRENT STATUS}

The ageing population and the decline in fertility are related, leading to a reduction in population growth and the creation of a new emerging family structure. Thus, techniques that interfere with reproduction contribute to this scenario. A new family profile is being observed. The quest to obtain a pregnancy has been for decades exceeding limits. The male reproductive potential status can result in more offspring in spite of increasing age. In fact, male and female lifetime strategies are as different as their mate selection criteria and the resulting cognitive differences. Azoospermia, the absence of spermatozoa in ejaculated semen, affects approximately $5 \%$ of all men and accounts for one-third of all male factor infertility cases. Obstructive azoospermia may be congenital or acquired (from vasectomy). In these cases, spermatozoa can be retrieved in $25-65 \%$ and pregnancy rates of $20-50 \%$ at different centres with in vitro fertilization and intracytoplasmic sperm injection (ICSI) (Nijs et al., 2011; Taitson et al., 2012). Most causes of male infertility are treatable, and the goal of many treatments is to restore the ability to conceive naturally. Varicocele is present in $15 \%$ of the normal male population and in approximately $40 \%$ of men with infertility. It is the most common cause of male infertility that can be corrected surgically. In males with azoospermia, the most common cause is post-vasectomy status. Approximately $6 \%$ of males who undergo vasectomy eventually seek reversal surgery. Success of vasectomy reversal decreases with the number of years between vasectomy and vasovasostomy. Other causes of obstructive azoospermia include epididymal, vasal or ejaculatory duct abnormalities. Epididymal obstruction is the most common cause of obstructive azoospermia. Patients with epididymal obstruction without other anatomical abnormalities can be considered as candidates for vasoepididymostomy. With microsurgical techniques, success of patency restoration can reach $70 \sim 90 \%$. In case of surgically uncorrectable obstructive azoospermia, sperm extraction or aspiration for in vitro fertilization is needed. Nonobstructive azoospermia is the most challenging type of male infertility. However, microsurgical testicular sperm extraction may be an effective method for nonobstructive azoospermia patients (Geber et al., 2012; Lee \& Seo, 2012). The process of spermatogenesis is essential for human reproduction. A simple sounding process is mediated by a variety of factors, including multiple hormonal influences. The gonadotropin-releasing hormone (GnRH), LH, Folliclestimulating hormone $(\mathrm{FSH})$, and testosterone all play an important role in the development and maturation of sperms. At the same time, various locally secreted peptides and proteins such as GH, IGF-1, cytokines, activin, inhibin, follistatin, and estrogen, exert autocrine and paracrine control over spermatogenesis. GH has an important physiological role to play in spermatogenesis and male fertility. More studies are required to define the exact place of $\mathrm{GH}$ therapy in clinical practice. Although it certainly merits a trial in $\mathrm{GH}$-deficient patients, it may be used in non-responding normogonadotropic idiopathic oligoasthenospermia. A close watch must be kept for metabolic side effects. Its true potential will be realized only if endocrinologists: both medical and reproductive, team together to analyze the patient populations and where it can be used (Madhukar \& Rajender, 2009; Magon et al., 2011).

The pathogenesis of male infertility can be reflected by defective spermatogenesis due to failure in germ cell proliferation and differentiation. This cell line undergoes meiosis and can develop into sperm when transplanted into germ cell depleted testicular tubules. Sperm were viable and functional, as shown by fertilization after intra-cytoplasmic injection into mouse oocytes. This approach provides the basis that is essential for studying the development and differentiation of male germ line stem cell, as well as for developing new approaches to reproductive engineering and infertility treatment (Nayernia et al., 2004).

\section{PRESERVING FERTILITY FOLLOWING MEDICAL THERAPIES}

The inaugural World Congress on Fertility Preservation was held from December 10-12, 2009 in Brussels under the auspices of the newly formed International Society of Fertility Preservation (ISFP). ISFP President Professor Jacques Donnez organized 
a three day program bringing together some 35 experts as speakers and over 350 clinicians and scientists from around the world participated. In breaking ground for what is rapidly emerging as an ever-increasing dictum to bring preventive medicine into the forefront of reproductive medicine, this conference served two novel and insightful functions: To bring focus to the special needs of cancer patients with

respect to their prospects for child bearing in the future, and to assess the status of clinical and basic science research in human reproduction pertinent to medical or environmental interventions that impact present and future fertility.

The substance of the congress left most in attendance with the view that while challenges remain, prospects were bright for fertility preservation to develop into an important field bringing previously unanticipated benefits for human health in general and infertility management in particular. The meetings overall structure was designed to achieve three goals: Set the stage for the clinical basis of the field, bear witness to the technologies that are under development that or are already making contributions to the treatment of patients, especially those being treated for cancer, and finally, engage the participants in a lively debate on the benefits and risks associated with the available technologies (Donnez et al., 2010).

Fertility should be discussed with all patients at risk of gonadal failure due to treatment. Ideally, this discussion should be held by a fertility expert with special interest in fertility preservation, but oncologists, hematologists, pediatricians or other specialists treating cancer patients can also address this issue with the patient before treatment. In case of minors, the discussion should take place together with the child $s$ parents. Cryopreservation of sperm should be offered to all men regardless of risk of gonadal failure. It is a simple, low cost and efficient method of preserving fertility, which most patients have time to undergo before treatment. In cases where it is difficult to produce a semen sample, for instance in the adolescent male, electro-ejaculation can be offered in order to obtain an ejaculate. For pre-pubertal boys the only option to secure fertility is cryopreservation of testicular tissue, but this is still experimental (Schmidt \& Andersen, 2012).

Modern treatment for cancer and some non-malignant diseases employs combination chemotherapy and/or radiotherapy which produce severe cytotoxic effects on the testis. Elective sperm cryopreservation programs provide such men, likely to be rendered temporarily or permanently infertile, the opportunity for paternity in a timely fashion. Both the numbers referred for cryostorage and of those seeking to use cryostored material, have increased progressively over recent years. The increasing use of elective cryopreservation facilities is probably due to better awareness of doctors, nurses, patients and their families that virtually any stored semen now has the potential to achieve a pregnancy resulting from a concomitant advance in reproductive techniques (Sanger et al., 1992).

There are several features of a spermatozoon necessary for fertilizing an egg which must be conserved after cryopreservation. The most important of these features can be summarized as DNA content, acrosomal integrity, motility, and viability. These vital parameters of spermatozoa in a fertile and healthy population were evaluated by means of several histological criteria, both before freezing and after thawing in order to assess the effects of cryopreservation. Sperm parameters and the vulnerability of spermatozoa may vary among populations which are healthy, infertile, or suffer from chronic diseases such as malignity and it is essential for the literature to understand the cryo-injury mechanisms of sperm (Meseguer et al., 2006; Ozkavukcu et al., 2008).

\section{PLURIPOTENT STEM CELL TREATMENT OPTIONS}

The primary function of the mammalian testis is the production of both gametes and hormones over a reproductive lifespan. This production of gametes proceeds in the seminiferous tubules and is supported by a stem cell population, the spermatogonial stem cells (SSCs). Like other tissue-specific stem cells, SSCs are defined by their ability to balance between self-renewal and differentiation. This balance maintains the stem cell pool and guarantees the daily production of spermatozoa from puberty onward. Studying SSCs is difficult because they are very few in number $(0.03 \%$ of all germ cells), and specific markers have not been identified so far. Most of our knowledge results from experiments in rodent models and very little is known about human SSCs (Goossens \& Tournaye, 2013).

Researchers were able to form sperm, ova and embryoid bodies from stem cells of mice. They also succeeded in producing human sperm cells from human stem cells derived from dental pulp stem, which were injected into the testes of rats that served as the vehicle for the growth of gametes. More recently, a British researcher found that he had produced functional human sperm from human embryonic stem cells. Days after publication his article has been removed from the journal by the absolute lack of evidence, proving to be more of a scientific fraud. In any case, these studies open up a vast field future in order to create gametes and embryos from somatic cells of the organism, which could perpetuate the human reproductive capacity.

\section{Correspondence}

Research Group Functional Anatomy of the Urogenital Apparatus Institut of Biological Sciences, Pontifical Catholic University of Minas Gerais

Av. Dom José Gaspar, 500/25

Belo Horizonte - Brazil

Telefone: 30535-510

e-mail: pftaitson@bol.com.br

\section{REFERENCES}

Donnez J, Kim SS, Albertini DF. Proceedings of the First World Congress on Fertility Preservation: executive summary. J Assist Reprod Genet. 2010; 27:191-5.

Easley CA et al. Stem cell therapeutic possibilities: future therapeutic options for male-factor and female-factor infertility? Reproductive BioMedicine Online. (in press) http://dx.doi.org/10.1016/j. rbmo.2013.03.003., 2013.

Geber S, Lemgruber M, Taitson PF, Valle M, Sampaio M. Birth of healthy twins after intracytoplasmic sperm injection using ejaculated immotile spermatozoa from a patient with Kartagener's syndrome. Andrologia. 2012; 44(Suppl 1):842-4.

Goossens E, Tournaye H. Adult stem cells in the human testis. Semin Reprod Med. 2013; 31(1):39-48.

Lee HS, Seo JT. Advances in surgical treatment of male infertility. World J Mens Health. 2012; 30(2):108-13.

Madhukar D, Rajender S. Review Hormonal treatment of male infertility: promises and pitfalls. J Androl. 2009; 30(2):95-112.

Magon et al,. Growth hormone in male infertility. Indian J Endocrinol Metab. 2011; 15(Suppl 3): S248-S9.

Meseguer M, Molina N, Garcia-Velasco JA, Remohi J, Pellicer A, Garrido N. Sperm cryopreservation in oncological patients: a 14-year follow-up study. Fertil Steril. 2006; 85:640-5.

Nayernia $\mathrm{K}$ et al. Stem cell based therapeutical approach of male infertility by teratocarcinoma derived germ cells. Hum Mol Genet. 2004; 13(14):1451-60.

Nijs M, De Jonge C, Cox A, Janssen M, Bosmans E, Ombelet W. Correlation between male age, WHO sperm parameters, DNA fragmentation, chromatin packaging and outcome in assisted reproduction technology. Andrologia. 2011; 43:174-9.

Ozkavukcu S, Erdemli E, Isik A, Oztuna D, Karahuseyinoglu S. Effects of cryopreservation on sperm parameters and ultrastructural morphology of human spermatozoa. J Assist Reprod Genet. 2008; 25(8): 403-11.

Sanger WG, Olson JH, Sherman JK. Semen cryobanking for men with cancer-criteria change. Fertil. Steril. 1992; 58: 1024-7.

Schmidt KT, Andersen CY; ISFP Practice Committee Recommendations for fertility preservation in patients with lymphomas. J Assist Reprod Genet. 2012; 29(6):473-7.

Taitson PF, Melo CS, Mancebo AC, Melo UB, B Souza MC. Pregnancy after percutaneous epididymal sperm aspiration in an 81-year-old man with obstructive azoospermia. Andrologia. 2012; (5):355-7. 